\title{
Agricultural resources management through a linear programming approach: A case study on productivity optimization of crop-livestock farming integration
}

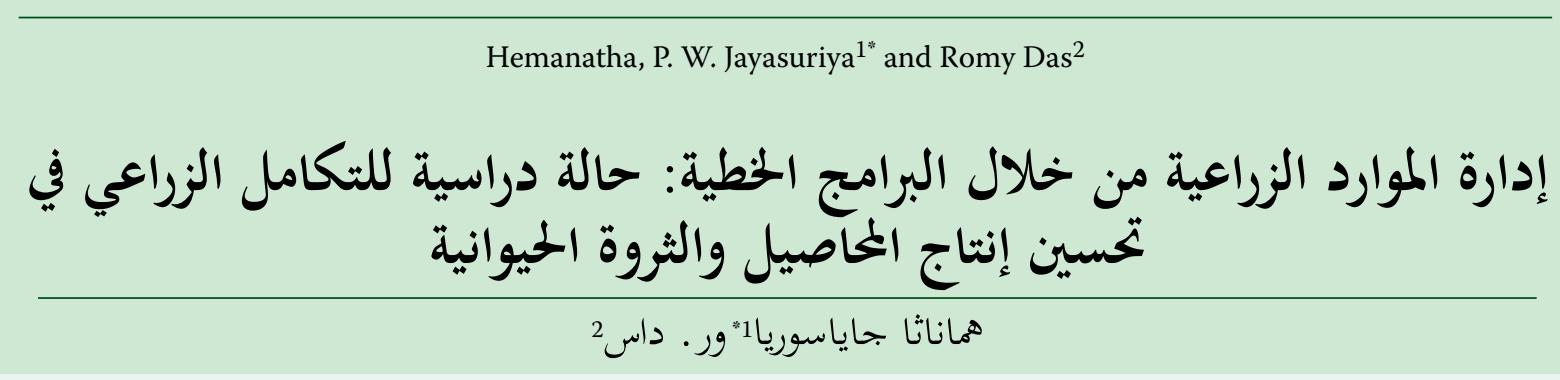

ABSTRACT. The crop-livestock integrated farming system practiced in most developing countries depends to a greater extent on the ecosystem as a whole. The importance of animals as an agent of nutrient recycle, sources of rural energy in terms of draft power and fuel as well as major contributor of the farm economy, has resulted into increased population of ruminant stock in these regions creating threats to the sustainability and productivity of land resources. This casestudy research attempted to formulate optimum herd size compatible to different resource holding farm categories within the sub watershed in mid hills region of Nepal. The research was conducted by classified data collection in Nepal and analysis using Linear Programming (LP) techniques. The LP analysis revealed that the farmers of large, medium and small categories of farms can optimize their livestock holding with combination of 3 Livestock Units (LU) buffaloes and $4 \mathrm{LU}$ goats, $2 \mathrm{LU}$ buffaloes and $4 \mathrm{LU}$ goats and $1 \mathrm{LU}$ buffaloes and $4.4 \mathrm{LU}$ goats with maximum return to the farm family without exerting pressure on the fragile natural resources.

KEYWORDS: Livestock Unit; land Resources; optimum herd size; total digestive nutrient supply

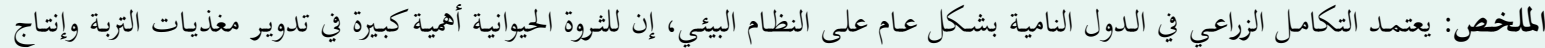

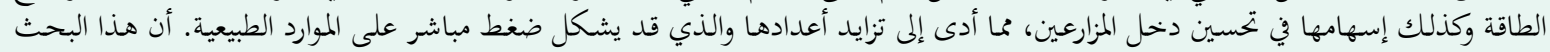

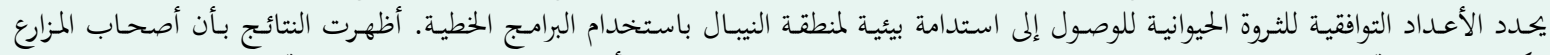

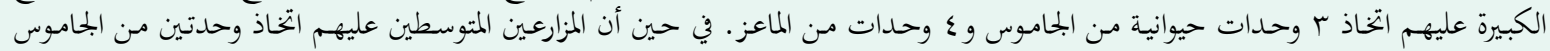

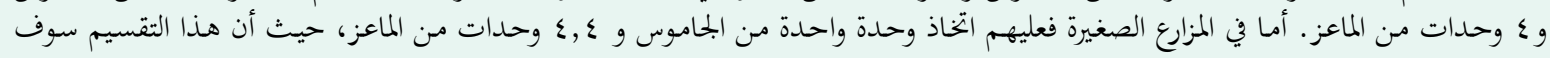

$$
\begin{aligned}
& \text { يقلل الضغط على الموارد } \\
& \text { الكلمات المفتاحية: وحدة الثروة الحيوانية، موارد الأراضي، إجمالي الجهاز الهضمي للعناصر الغذائية }
\end{aligned}
$$

\section{Introduction}

1 he diverse climatic conditions of Nepal has enabled its people to practice various forms of agricultural activities. Farming takes place from the Terai region to the permanently cultivated land above $4000 \mathrm{msl}$ (Schroeder, 1985). At higher altitude, livestock plays the most prominent role in the livelihood and people are mostly pastoralist, whereas in fertile plains, the emphasis is on crop production. In the broad band between high hills and lower mountains area, farmers mostly rely on the century's old tradition of integrated and diversified mixed crop-livestock farming (Sumberg, 2003; Bell and Moor, 2012). Crop-livestock integration is thus the established characteristics of the hills of $\mathrm{Ne}$ pal. The role of livestock as nutrient recyclers, source of income and draft power obligates farmers to keep large

\footnotetext{
${ }^{* 1}$ Hemanatha P.W. Jayasuriya ( Sultan Qaboos University, College of Agricultural and Marine Sciences, Dpt. of Soils, Water and Agricultural Engineering, Box 34, Al-Khod 123, Sultanate of Oman. Email: hemjay@squ.edu.om. ${ }^{2}$ Agricultural Systems and Engineering Program, Asian Institute of Technology, Klong Luang, Pathumthani 12120, Thailand.
}

number of livestock leading to high livestock population in the country. Mid hilly region of the country has approximately two third of the country's livestock population. Livestock density in Nepal is the highest among South Asian countries. It has been estimated to be 6.52/ ha, which is higher than 3.99 ha, the density in Bangladesh, where similar climatic and economic conditions exists (FAO, 1990).

Excessive grazing on natural forests due to high livestock population in the hills has resulted into severe deterioration in the growth of shrubs and trees. The ground cover to limit soil erosion is either at a minimum or has vanished. The higher livestock population is not only a pressure on the resources but has also negative impact on the productivity (Anderson, 1997; Bell and Moor, 2012). The majority of the livestock in the hill districts of Nepal suffers from low nutrition. Even though the animals are of high genetic potential, poor nutrition negatively affects production (Regmi 1992). The mid hills of Nepal have tremendous potential for dairy production, but its productivity remains vulnerable due to diminishing availability of feed resources and growing number of unproductive animals. 
High livestock population pressure on the natural resource base as well as on agricultural land is the result of farmers' poor decisive ability regarding herd size (Price and Hacker, 2009; Bell and Moor, 2012). Rural farmers are mostly confronted with the problem of properly allocating scarce land and labor resources in a crop and livestock mix farming system (Minh et al. 2007). Reaping maximum benefits from available resources necessitates proper farm planning to utilize the resources more effectively for crop and livestock production without exerting additional pressure on natural resources (Millar and Badgery, 2009). Efficient farm planning regarding livestock holding will further contribute to the economic and sustainable development of the watershed (Agrawal and Heady, 1972; Beneke and Winterboer, 1973; Igwe et al., 2011; Andreea and Adrian, 2012).

Although an assessment of carrying capacity in terms of livestock unit is a useful tool for planning as well as policy formulation, it is unable to infer directly the number and the composition of livestock in the farmers' household (Robertson et al., 2009; Govindrao and Kabeer, 2011). In fact, livestock rearing not only depends upon the feed available but also on the labor availability because livestock rearing is labor intensive. In this context, it is important to formulate the optimum livestock number based on the available resources to the farmers. Tulachan (1989) signified the importance of livestock to enhance the farm income of the rural farmers with the recommendation of various herd size suitable for different farm categories. Minh et al., (2007) showed the feasibility of optimizing the crop-livestock integration with an additional component of crop-residue-dung compost fertilizer use. Similarly, Regmi (1992) carried out an economic analysis of the farming system and formulated optimum farm plan with equal focus on crop and livestock as enterprises. But both of these studies were conducted in terai and did not represent the conditions of mid-hills where the livestock raising contributes significantly to the farm economy. Therefore, this study attempted to formulate the optimum livestock number and its composition, which gives high income to farm family with variable resources, using LP technique.

\section{Methodology}

\section{Site election}

The study was conducted in Kumpur subwatershed of Dhading district. The watershed covers an area of 66.2 ha, which occupies $3.45 \%$ of the total area of the dis- trict. It comprises Kumpur village development committee completely, Sunaula Bazaar and Kalleri partially. The sub watershed constitutes four micro-watersheds covering major tributaries as Adam, Bijuli, Sakura and Thopal Khola of Trishuli River. The elevation within Kumpur sub watershed varies approximately from 446 $\mathrm{m}$ near the Trishuli River to approximately $1570 \mathrm{~m}$ at the north-eastern corner of the study area. Due to variation in the altitude, a wide range of farming systems can be found even within small sub watershed.

\section{Data Collection}

The outcome of the research is based on primary as well as secondary data collected in Kumpur Sub watershed of Dhading district. The methods of primary data collection were household survey, group discussion and field observation. Similarly, secondary data were collected from annual reports of District Livestock Service Centre, District Soil Conservation Office, District Forest Office, Locally based NGOs and VDC profile. Similarly, publications of International Centre for Integrated Mountain Development, articles from International journals and textbooks served as important sources of secondary data. Collected data were analyzed using SPSS (Statistical Package of Social Science). Farm plans for three categories of farmers were formulated using linear programming tools.

\section{Data Analysis}

\section{The linear programming (LP) technique}

Farmers in hilly region of the country possess very limited resources particularly land, labor and capital. In case of poor resources holding at their own, as well as dwindling supply from common pool resources, it is essential to estimate the best combination of available farm resources to maximize the net farm income. The overall goal of farmers to maximize the farm income with optimum resource allocation allows the use of the LP technique as an appropriate decision making tool in the analysis (Agrawal and Heady, 1972; Beneke and Winterboer, 1973; Hillier and Liberman, 2001; Minh et al., 2007; Soltani et al., 2011; Govindrao and Kabeer, 2011). Using the shadow prices and sensitivity analysis, ranking of livestock components was done allowing farmers to select the best among several options considering the sociological and economical factors.

Mathematically, a linear programming (LP) model can be expressed as follows:

Table 1. Farm categorization of the sampled households

$\begin{array}{lll}\text { Farm categories } & \text { Land holding } & \text { No. of farm household } \\ \text { Small Farm } & <0.5 \text { ha } & 58 \\ \text { Medium Farm } & 0.5-<1 \text { ha } & 57 \\ \text { Large Farm } & >1 \text { ha } & 45\end{array}$




$$
Z_{\max }=\sum_{i=1}^{j} C_{i} X_{i}
$$

subjected to

$$
\text { Resources constraints } \sum_{i=1}^{n} \sum_{j=1}^{m} a_{i j} X_{i} \leq b_{j}
$$

and

$$
\text { Non-negative constraints } \quad X_{i} \geq 0
$$

where

$$
\begin{aligned}
& Z=\text { The objective function } \\
& x_{j}=\text { The level of the } j^{\text {th }} \text { decision variable } \\
& c_{j}=\text { Gross margin of unit of the } j^{\text {th }} \text { activity } \\
& a_{i j}=\text { The quantity of the } \mathrm{i}^{\text {th }} \text { resource required to produce } 1 \text { unit of } j^{\text {th }} \text { activity } \\
& m=\text { The number of resources } \\
& m=\text { The number of possible activities } \\
& b_{i}=\text { The amount of the } \mathrm{i}^{\text {th }} \text { resource available } \\
& i=1,2, \ldots m ; \quad j=1,2, \ldots . n
\end{aligned}
$$

\section{Farm classification}

Farmers of the study area differed in resource availabilities. Resource holding in terms of land, family labor and livestock number were the main basis for farms categorization for the LP analysis. However, land holding size served as a major criterion for farm categorization in the model. Livestock Master Plan (1993) also categorized the farm families into large, medium and small farm based on their land holding size. Farmers of the study area were also classified into three groups based on the above criteria. The total 160 sample households were categorized into three groups as given below.

The average value of resources such as land, labor, nutrient availability and livestock holdings of sampled farm household were used to construct a representative of three farm categories and linear programming model was run for each representatives farms.

\section{Assumptions made in LP Model}

(1) Crop residues or crop by-product used as main sources of animal feeds for livestock production. The use of crop residue, such as rice straw, maize stover was considered as transfer activities in the integrated farming system. Rice straw was produced in the winter season and stored as feed for rest of the year. Crop residue, as feed sources were considered without their opportunity cost in the model. Similarly, manure production from livestock was considered to be used in the crop production as Farm Yard Manure (FYM).

(2) Return from the bullock was calculated based on the number of days, they are placed for work. Since their use was seasonal, it was assumed that a pair of bullock is used approximately for 180 days in cropping activities. Tulachan (1989) adopted the same method to calculate the return from the draft power use of bullock.

(3) Family labor and use of own bullock was considered without their labor cost. For crop production, cost of hired labor was included. However, it was assumed that livestock production is entirely performed through family labor. Returns received from the linear programming solution were return to farm labor, family owned bullock and land. Capital cost of each type of livestock in the model was considered using market price and current interest rates.

(4) The main economic animals considered for the models were milking buffaloes, milking cows, draft bullocks and goats. The model only considered adult animals which gives economic return.

(5) Livestock were assumed to be raised with two different feeding management systems. The existing farm plan had taken into account maintenance ration only whereas improved feeding with maintenance and production rations was considered in the improved farm plan.

Decision Variables Used in Linear Programming Model

\section{A. Cropping activities}

Rice and maize were the major cereal crops used as staple food in the study area. Additionally, these were the major sources of crop residues for livestock feed. Therefore, these two crops had been taken as only cropping activities in the model. Production cost per unit was deducted from the per unit output value of each cropping activities to get the gross return.

\section{B. Livestock enterprises}

Each type of livestock unit (LU) was considered as a separate activity in the model. Balancing the livestock carrying capacity (=LU) for each type of livestock, based on TDN requirement, 4 goats were considered as one LU. Since the main objective of the model was to determine the optimum stocking for each farm categories, the number and type of livestock was selected based on available feed resources. Milk production was considered as a major output from cattle and buffaloes. Similarly, draft power use during working periods was considered for the calculation of return from bullock. Return from goat indicated the economic value of meat produced per year. Return from livestock activities was estimated without including the cost of feeds except concentrate. Due to improved feeding, comparatively higher return from buffalo milk production was considered in improved farms plans than the existing plan.

\section{Fodder plantation}

Grazing a large flock of goats was difficult under the community sanction of common pool resources in the study area. Moreover, considering the negative effects of the browsing nature of goats on vegetation cover, increased number of goats might require increased farm 
Table 2. Cultivated land holding of farm categories.

$\begin{array}{lccc}\text { Farm category } & \text { Total land holding (ha) } & \text { Upland holding (ha) } & \text { Lowland holding (ha) } \\ \text { Large Farm }(\mathrm{n}=45) & 1.75 & 1.25 & 0.5 \\ \text { Medium arm }(\mathrm{n}=57) & 0.8 & 0.52 & 0.28 \\ \text { Small Farm }(\mathrm{n}=58) & 0.43 & 0.26 & 0.17\end{array}$

Source: Household survey, Primary data

fodder production. Therefore, to minimize the dependency on external sources, certain proportion of upland area was considered under fodder tree plantation in all improved farm plans so that stall-feeding of large number of goats can be possible and grazing in common pool resources can be minimized. Since fodder tree occupies certain area under cultivated land, it was considered as a separate activity in the improved farm model. The economic return from fodder tree was calculated with respect to the Total Digestive Nutrient (TDN) value of crop residue.

\section{Farm resources and constraints used in LP model}

A farmer has to take decisions regarding cropping and livestock activities within the boundary of resources available to the farm household. The major resources that a farmer owns are the land, family labor and the capital. These resources are limited for the family therefore, they demand efficient use. The resources considered in the model are discussed as follows.

\section{A. Land resources}

Land is a scarce resource for the hill farmers of Nepal. Efficient allocation of land is an important factor to be considered in increasing whole farm income. Table 2 presents the land holding of three farm categories. The

Table 3. Cultivated land holding of farm categories.

\begin{tabular}{|c|c|c|c|c|c|c|}
\hline Age Category & Heads & $\begin{array}{c}\text { Labor } \\
\text { Equivalent }\end{array}$ & $\begin{array}{l}\text { Estimated } \\
\text { LD/month }\end{array}$ & $\begin{array}{l}\text { LD/Month in } \\
\text { farming }\end{array}$ & $\mathrm{LD} /$ year for & $\begin{array}{l}\text { Labor hours avail- } \\
\text { able for farming }\end{array}$ \\
\hline \multicolumn{7}{|l|}{ Large Farm } \\
\hline$<0-15 y r s$ & 2.42 & 0.5 & 15 & 3 & 72 & 576 \\
\hline $16-59$ yrs & 3.23 & 1 & 30 & 25 & 900 & 7200 \\
\hline$>60 \mathrm{yrs}$ & 0.44 & 0.5 & & 4 & 19.2 & 153.6 \\
\hline Total & & & & & & 7929 \\
\hline \multicolumn{7}{|l|}{ Medium Farm } \\
\hline$<0-15 y r s$ & 2.47 & 0.5 & 15 & 3 & 72 & 576 \\
\hline $16-59$ yrs & 2.86 & 1 & 30 & 25 & 900 & 7200 \\
\hline$>60 y r s$ & 0.37 & 0.5 & 15 & 4 & 14.4 & 115.2 \\
\hline Total & & & & & & 7891 \\
\hline \multicolumn{7}{|l|}{ Small Farm } \\
\hline$<0-15 y r s$ & 1.81 & 0.5 & 15 & 3 & 72 & 576 \\
\hline $16-59$ yrs & 3.02 & 1 & 30 & 25 & 900 & 7200 \\
\hline$>60 y r s$ & 0.28 & 0.5 & 15 & 4 & 9.6 & 76.8 \\
\hline Total & & & & & & 7852 \\
\hline
\end{tabular}

cultivated land holding was categorized into upland (unirrigated land) and lowland (irrigated land) in each farm category. Rice is grown in the irrigated land therefore the total available irrigated land was considered as land constraints under rice cultivation. Since there was hardly any option for further increasing the landholding and land type of the farm household, no attempt was made to increase land area under rice and maize in the model.

Maize is usually grown in the upland of the area; therefore, bari land (unirrigated land) was taken as constraints for the area under maize. Fodder trees are grown on the riser and bunds and occupy a certain area of the bari land. Fodder trees are rarely cultivated in khet land due to its shading effect on the crop yield. According to LRMP (1986), about $17.4 \%$ of gross cultivated area in Kavrepalanchowk district of Nepal is under riser and bunds. The same figure was assumed in the study area as well. Therefore, the upland area with same figure was allocated under the fodder tree as an equality constraint in the improved farm model.

Labor is the most important resource for crop as well as livestock activities. Cropping activities are seasonal

\section{B. Labor resources}

Source: Household survey, primary data 
and required to be performed within a specified period of time. Delay in one of the activities may affect the other. In contrast, livestock activities are neither seasonal nor they have sequential effect upon each other. Therefore, the later activities are usually carried out by family labor.

Livestock management in the study area was found as a full time job for one family member of a household in the study area. Forest fodder collection and grazing were the most time consuming activities for the livestock management. Crop production consumed family as well as hired labor but livestock production mostly depended upon the family labor. Farmers reported that family labor was not enough during the peak period of crop cultivation. Therefore, hired labor was essential to perform several activities in time.

Table 3 shows family labor calculation in three farm categories. It was calculated according to the labor-days available in the farming activities. The same method of family labor calculation was adopted by Regmi (1992). Labor-days (LD) available for farming activities per month was calculated based on the age and health condition of the each member. Finally, labor per month was converted into annual labor hour available for farming.

\section{Livestock and feed resources}

Livestock contributes significantly to the sustainability as well as household income of a farming family. Therefore, it has been considered as a major resource of the farm. The major ruminant animals reared by the farmers of study area were milking cow, buffalo, bullock and goats. They receive high income from milk and meat trading. Therefore, milking cow, buffalo, draft bullock and goats were considered as source of economic return in the farm model. The livestock used in the model were of local breads. Table 4 shows the number and types of livestock reared by the three farm categories. Livestock in the study area were mainly reared on crop residue, crop- by products, tree leaf fodder from farm land as well as supply from common property resources and wasteland through grazing, cut grasses/weeds and leaf fodder.

Furthermore, they were fed with the home produced maize flour and by-products such as rice bran as con-

Table 4. Livestock holding by farm categories

\begin{tabular}{|c|c|c|c|c|c|c|}
\hline \multirow[t]{2}{*}{ Types of Livestock } & \multicolumn{2}{|c|}{ Large Farm $(n=47)$} & \multicolumn{2}{|c|}{ Medium farm $(n=57)$} & \multicolumn{2}{|c|}{ Small Farm $(n=58)$} \\
\hline & Mean & Std. & Mean & Std. & Mean & Std. \\
\hline Cow & 1.5 & 1.47 & 1.4 & 1.4 & 1.2 & 0.84 \\
\hline Bullock & 1.72 & 0.87 & 1.61 & 1.03 & 1.38 & 0.92 \\
\hline Cattle calves & 0.33 & 0.79 & 0.21 & 0.64 & 0.28 & 0.61 \\
\hline Buffalo & 1.72 & 1.16 & 1.19 & 0.98 & 1.43 & 0.77 \\
\hline Buffalo calves & 0.82 & 0.76 & 0.52 & 0.61 & 0.48 & 0.89 \\
\hline Goat & 5.88 & 3.10 & 5.08 & 4.00 & 5.55 & 2.18 \\
\hline
\end{tabular}

Source: Household survey, Primary data centrate feed. Improved fodder grasses and forage crops plantation was not common in general. Table 5 shows feed supply from various sources, which were considered as maximum feed supply in the farm model. Feed supply has been considered in term of Total Digestive Nutrient (TDN).

\section{Results and Discussion}

\section{Optimization of Livestock Holding Using LP method}

The study attempted to formulate the optimum number and combination of livestock that should be reared by the households with different resource holdings. To formulate the optimum number and composition of livestock in crop-livestock integrated farming system, the study used linear programming as a main analytical tool. Using the shadow prices of decision variables and the sensitivity analysis, different combination of livestock number, which gave maximum income to the farm household, were selected as optimum herd size. Since the livestock population of subwatershed was above the carrying capacity of resources, optimum herd size was formulated without significantly increasing their existing herd size (Table 6).

\section{Optimum livestock holding for small farm size}

The representative of small farm size in the study area consisted of six members with an average of 2 members under age group 0-15 years and 3 members belonging to 16-59 years. The small farm size had annual family labor of 7852 hours ( 981 man- days). In an average a farm household in this category collected $3.8 \mathrm{mt} / \mathrm{yr}$ TDN from different sources. The total cultivated land holding size of small farm category was 0.43 ha out of which irrigated land is 0.17 ha and unirrigated land 0.26 ha. Rice was mainly grown in lowland (irrigated) areas whereas maize was grown in upland area (unirrigated). Besides crop production, the farmers under small farm category, reared in on average 1 milking cow, 1 milking buffalo, 1 bullock and 6 goats. With the existing resources, this farm category received 40133 NRs per year (Table 7). 
Table 5. TDN supply from various sources of feed ( $\mathrm{kg} /$ year).

\begin{tabular}{|c|c|c|c|c|c|c|}
\hline \multirow{2}{*}{$\begin{array}{c}\text { Types of Live- } \\
\text { stock }\end{array}$} & \multicolumn{2}{|c|}{ Large Farm $(n=45)$} & \multicolumn{2}{|c|}{ Medium farm $(n=57)$} & \multicolumn{2}{|c|}{ Small Farm $(n=58)$} \\
\hline & Mean & Std. & Mean & Std. & Mean & Std. \\
\hline Rice Straw & 480.25 & 410 & 329.02 & 273.45 & 245.69 & 296.56 \\
\hline Millet Straw & 34.94 & 52 & 40.89 & 79.84 & 29.39 & 43.67 \\
\hline Wheat straw & 4.26 & 11 & 4.77 & 17.0 & 4.18 & 12.5 \\
\hline Maize Stover & 293 & 185 & 236.88 & 183.7 & 248.0 & 200.0 \\
\hline Maize cob & 14.83 & 15.6 & 9.72 & 10.78 & 10.41 & 11.4 \\
\hline Pulse residue & 3.56 & 0.88 & 3.8815 & 1.14 & 3.60 & 1.140 \\
\hline Maize flour & 1036.11 & 1867 & 685.45 & 419.67 & 585.42 & 278.8 \\
\hline Rice bran & 95.86 & 195 & 58.46 & 120.67 & 16.2 & 62.5 \\
\hline Farm grass & 1711.90 & 361.6 & 310.24 & 321.4 & 285.30 & 457.7 \\
\hline Fodder tree & 480.24 & 1138 & 310.24 & 178.6 & 285.30 & 222.6 \\
\hline Forest fodder & 1175.82 & 494.7 & 1958.742 & 690. & 1819.96 & 641.7 \\
\hline Grazing Supply & 274.68 & 158.43 & 268.26 & 133.5 & 269.72 & 164.0 \\
\hline Total & 5606 & & 4506 & & 3803 & \\
\hline
\end{tabular}

Source: Household survey, Primary data

The LP analysis revealed that the small farm categories with the above resources holding can optimize their herd size with $1 \mathrm{LU}$ of buffalo and $4 \mathrm{LU}$ of goat with $32 \%$ increase in gross income and $45 \%$ return in family labor

\section{Optimum livestock holding for medium farm size}

Medium farm family in the study area has total cultivated land holding of 0.83 ha with irrigated and unirrigated land 0.28 and 0.55 ha respectively. The household within the medium land holding consists of an average of 2 members belonging to age group $0-15$ years and 3 members within age group, 15-59 years. The total annual family labor availability for farming activities is 7891 hrs (986 man-days). On an average, a farm household in this category collects $4.5 \mathrm{mt} / \mathrm{yr}$ of TDN from different source. The medium category of farm possess one LU of milking cow, one LU buffalo, 2 LU bullock and 1.5 LU goats (6 goats) and receives annual gross return of 49,158 NRs per year under the above mentioned crop and livestock activities whereas $2 \mathrm{LU}$ of milking buffalo and 3.5 LU goats (14 goats) has been found as optimum livestock holding for medium farm family with the maximum use of above-mentioned land, labor and TDN supply. Medium farm family can increase their gross income with $35 \%$ and return at family labor by $49 \%$ with optimum herd size.

Table 6. Optimum herd sizes for three categories of farm households.

\begin{tabular}{llll}
\multicolumn{1}{c}{ Decision variable } & Small Farm & Medium farm & Large Farm \\
Gross Return (NRs) & 53059.50 & 66711.84 & 91830.58 \\
Cropping activities (ha) & & & 0.5 \\
Rice & 0.17 & 0.28 & 1 \\
Maize & 0.22 & 0.5 & 0.2 \\
Fodder Plantation (ha) & 0.04 & 0.08 & - \\
Optimum herd size (LU) & & & 3 \\
Cow & - & - & - \\
Buffalo & 1 & 2 & $4(16$ goats) \\
Bullock & - & - & 99884 \\
Goat & $4(16$ goats) & $4(16$ goats) & $(72 \%)$ \\
Contribution of & 47516 & 54956 & $(82 \%)$ \\
livestock (NRs*) & $(86 \%)$ & 173 & 195 \\
Return over family labor (NRs) & 170 & &
\end{tabular}

* There is no indication 
Table 7. Comparison of system economics of current and simulated for all farm categories and three optional plans with respective gross returns to choose

\begin{tabular}{|c|c|c|c|c|c|}
\hline \multirow{2}{*}{$\begin{array}{c}\text { Farm } \\
\text { Category }\end{array}$} & \multirow{2}{*}{ Decision variables } & \multirow{2}{*}{ Existing farm plan } & \multicolumn{3}{|c|}{ Improved farm plans (LP simulated) } \\
\hline & & & Plan 1 & Plan 2 & Plan 3 \\
\hline \multirow{11}{*}{ Small } & Cropping activities (ha) & & & & \\
\hline & Rice & 0.17 & 0.17 & 0.17 & 0.17 \\
\hline & Maize & 0.26 & 0.22 & 0.22 & 0.22 \\
\hline & Fodder & - & 0.04 & 0.04 & 0.04 \\
\hline & Livestock activities (LU) & & & & \\
\hline & Cow & 1 & 1 & - & - \\
\hline & Buffalo & 1 & 1 & 1 & 1 \\
\hline & Bullock & 1 & 1 & 1 & - \\
\hline & Goat & 1.5 (6 goats) & 2 (8 goats) & 2.8 (11 goats) & 4 (16 goats) \\
\hline & Gross return (NRs) & 40132 & 13432 & 47341 & 53060 \\
\hline & $\begin{array}{l}\text { Contribution of livestock } \\
\text { (Nrs) }\end{array}$ & $\begin{array}{l}74 \% \\
(362012)\end{array}$ & $\begin{array}{l}76 \% \\
(37658)\end{array}$ & $\begin{array}{l}78 \% \\
(42898)\end{array}$ & $\begin{array}{l}82 \% \\
(54956)\end{array}$ \\
\hline \multirow{11}{*}{ Medium } & Cropping activities (ha) & & & & \\
\hline & Rice & 0.28 & 0.23 & 0.23 & 0.23 \\
\hline & Maize & 0.55 & 0.5 & 0.5 & 0.5 \\
\hline & Fodder & - & 0.08 & 0.08 & 0.08 \\
\hline & Livestock activities (LU) & & & & \\
\hline & Cow & 1 & 1 & - & - \\
\hline & Buffalo & 1 & 1 & 1 & 2 \\
\hline & Bullock & 2 & 2 & 2 & - \\
\hline & Goat & 1 (4 goats) & 1.3 (5 goats) & 2 (8 goats) & 4 (16 goats) \\
\hline & Gross return (NRs) & 49158 & 50526 & 54653 & 66712 \\
\hline & $\begin{array}{l}\text { Contribution of livestock } \\
\text { (Nrs) }\end{array}$ & $\begin{array}{l}74 \% \\
(36212)\end{array}$ & $\begin{array}{l}76 \% \\
(37658)\end{array}$ & $\begin{array}{l}78 \% \\
(42898)\end{array}$ & $\begin{array}{l}82 \% \\
(54956)\end{array}$ \\
\hline \multirow{11}{*}{ Large } & Cropping activities (ha) & & & & \\
\hline & Rice & 0.5 & 0.5 & 0.5 & 0.5 \\
\hline & Maize & 1.2 & 1 & 1.0 & 1.0 \\
\hline & Fodder & - & 0.2 & 0.2 & 0.2 \\
\hline & Livestock activities (LU) & & & & \\
\hline & Cow & 1 & 1 & - & - \\
\hline & Buffalo & 2 & 2 & 2 & 3 \\
\hline & Bullock & 2 & 2 & 2 & - \\
\hline & Goat & 1.5 (6 goats) & 1.7 (7 goats) & 2 (8 goats) & 4 (16 goats) \\
\hline & Gross return (NRs) & 76745 & 75414 & 78552 & 91831 \\
\hline & $\begin{array}{l}\text { Contribution of livestock } \\
\text { (Nrs) }\end{array}$ & $\begin{array}{l}67 \% \\
(48826)\end{array}$ & $\begin{array}{l}66 \% \\
(50310)\end{array}$ & $\begin{array}{l}68 \% \\
(53606)\end{array}$ & $\begin{array}{l}72 \% \\
(66884)\end{array}$ \\
\hline
\end{tabular}

For goats $1 L U=4$ adult goats

Optimum livestock holding for large farm size

Large farm size in the study area possessed comparatively higher resources than the other two farm categories. It has total cultivable land holding of 1.75 ha with 1.2 ha irrigated (Khet land) and 0.55 ha of irrigated upland (Bari land). Households in large farm size category consists of two members belonging to age group $0-15$ years, three members between age 16-59 years and one elder member of more than 60 years of age. The total family labor availability in large farm size is $7929 \mathrm{hrs} / \mathrm{yr}$ (991man-days/yr). On an average, a farm household in this category collects $5.6 \mathrm{mt} / \mathrm{yr}$ of TDN from different sources. A farm household receives annual gross return of NRs 76745 per year with 0.5 and 1.2 ha of land al- 
located for rice and maize respectively as well as from livestock activities. Livestock herd in this farm category is composed of a pair of buffaloes, a pair of bullocks, one cow and six goats.

Since the large farm category has comparatively higher resources holding than other farm categories, they are able to rear up to $3 \mathrm{LU}$ of buffalo. Thus the large farm categories can optimize their livestock holding up to 3 LU of buffalo and $4 \mathrm{LU}$ of goats (16 goats) with $19 \%$ increase in gross return and $40 \%$ increase in return at family labor.

\section{Other optional crop-livestock plans}

In addition to the constraints on economic and direct resources for crop-livestock activities, other sociological and agro-ecological aspects can be incorporated in the system by proper modelling and mathematical conversions of such linear functions. As an example, farmers in some systems can have a milking cow for family nutrient supply or a bullock for land preparation and transportation by sacrificing a little reduction in optimum economic return.

Table 7 shows the optimum crop-livestock combinations under three such plans compared with the current systems, in which farmers can chose the appropriate plan considering their conditions and requirements. Respective optimum economic returns under each plan and crop-livestock optimization was based on sensitivity analyses conducted in the program. Smaller farms show the highest livestock contribution contrarily by large farms. Three plans shows increasing trend of livestock contribution, the Plan III showing the optimal condition. Some additional benefits due to increase in livestock number were not taken in to the analysis such as soil nutrition improvement by the increased dong manure generation etc.

\section{Conclusion}

Findings of the linear programming revealed that with the current feed resources capacity, farmers in the study area could maximize their farm income from crop-livestock system without creating excessive pressure on the land resources and contribute towards sustainability of resources at the same time. Since the resources holding of farmers varies among each other, livestock carrying capacity at the household level also varies with farmers with different resources capacity.

Farmers in the large, medium and small farm categories can raise livestock up to $3 \mathrm{LU}$ buffaloes and $4 \mathrm{LU}$ goats, 2 LU buffaloes and 4 LU goats and 1 LU buffalo and 4.4 LU goats respectively according to their resources capacity. Farmers of these farm categories can maximize their benefit up to $19 \%, 34 \%$ and $32 \%$ from the improved farm plan with high return at the family labor than the existing farm plan. In all proposed farm plans I to III, contribution of livestock in gross return was found higher in small and medium farm categories than in the large. It indicates that a livestock enterprise in the study area is most profitable for low resource holding farmers. Among the herd composition, buffalo and goat rearing have proven more promising than cattle in terms of profit maximization.

Furthermore, high return to the farm household labor shows potential for solving the problem of unemployment and under employment. Gross margin analysis in all improved farm plans showed high return at family labor reflecting better employment opportunities of the farm labor in all farm categories. Considering the sociological factors as well as household requirements, farmers have to sacrifice their economic return in substantial amount.

\section{References}

Agrawal, R. C. and Heady, E.O. 1972. Operational methods for agricultural decisions. Iowa State University Press, Ames.

Anderson, B. 1997. Testing livestock feeds for beef cattle, Dairy Programme. Study of global change. $\mathrm{Hu}-$ man dimension of global environment change programme, Stockholm and Geneva.

Raluca, A.I. and Adrian,T.R. 2012. Linear programming in Agriculture: Case study in region of development South-Mountenia. International Journal of Sustainable Economies Management, 1(1), 51-60, doi: 10.4018/ijsem.2012010105.

Bell L. W., and Moore, A.D. 2012. Integrated crop-livestock systems in Australian agriculture: Trends, drivers and implications. Agricultural Systems 111:1-12.

Beneke, R.R. andWinterboer, R. 1973. Linear Programming applications to agriculture. Ames: The Iowa, State University Press.

FAO 1981. Report of the seventh session of the FAO Regional Commission on Farm Management for Asia and Far Eastern. Held in Jog Jakarta, Indonesia. 24-29 August 1981.

Govindrao, S. R. and Kabeer, S. J. 2011. Linear programming problem (LPP) and geographic information systems (GIS): A joint venture to optimize land utility. Journal of Statistics and Mathematics, 2(2): 59-62, ISSN: 0976-8807.

Hillier, F.S. and Lieberman, G.J. 2001. Introduction to Operation Research. McGraw-Hill publishing Company, New York.

HMG/N. 1993. Livestock Master Plan. His Majesty's Government of Nepal

Igwe, K.C., Onyenweaku, C.E. and Nwaru, J.C. 2011. Application of linear programming to semi-commercial arable and fishery enterprises in Abia State, Nigeria. International Journal of Economics and Management 
Sciences, 1(1); 75-81.

LRMP. (1986). Agriculture and Forestry Report. Land Resource Mapping Project Kathmandu. Kenting Earth Sciences, Canada and Department of Topography. HMG/Nepal.

Millar, G.D. and Badgery, W.B. 2009. Pasture cropping: a new approach to integrate crop and livestock farming systems. Animal Prod. Sci. 49, 777-787.

Minh Thai Thi, Ranamukhaarachchi S. L., and Jayasuriya, H. P. W. 2007. Linear Programming-based optimization of the productivity and sustainability of crop-livestock-compost manure integrated farming systems in midlands of Vietnam. Science Asia 33: 187-195.

Price, R.J. and Hacker, R.B. 2009. Grain and graze: an innovative triple bottom line approach to collaborative and multidisciplinary mixed-farming systems research, development and extension. Animal Prod. Sci. 49, 729-735.

Regmi, P. P. 1992. Economic analysis of the farming system of Shivnagar Village, Nepal: A linear programming approach. Unpublished AIT Thesis No.HS-92-26. Bangkok, Thailand.
Robertson, M.J., Bathgate, A., Moore, A.D., Lawes, R.A. and Lilley, J.M. 2009. Seeking simultaneous improvements in farm profit and natural resource indicators: a modelling analysis. Animal Prod. Sci. 49: 826-836.

Schroeder, R. F. (1985). Himalayan subsistence systems indigenous agriculture in rural Nepal. Mountain Research and Development. 5 (1): 31-44.

Soltani, J., Karbasi, A. R. and Fahimifard, S. M. 2011. Determining optimum cropping pattern using Fuzzy Goal Programming (FGP) model. African Journal of Agricultural Research Vol. 6(14), pp. 3305-3310, doi: 10.5897/AJAR11.585.

Sumberg, J. 2003. Towards a dis-aggregated view of crop-livestock integration in Western Africa. Land Use Policy 20: 253-264.

Tulachan, P.M. 1989. Potential contribution of livestock sector development to farm income and employment in the Chitwan Valley of Nepal. Unpublished Ph.D. Dissertation. Cornell University, USA. 